\title{
Analysis of repair works to remove the effects of structural failure after a gas explosion
}

\author{
Aleksandra $\mathrm{Bąk}^{1,{ }^{*}}$, Ryszard Chmielewski ${ }^{1}$ \\ ${ }^{1}$ Military University of Technology, Faculty of Civil Engineering and Geodesy, Warsaw, Poland
}

\begin{abstract}
The article presents the issues of repair works in a multi-family residential building, whose structural and non - structural elements have been damaged and destroyed by a gas explosion and the fire. Gas explosions in residential buildings constitute a small percentage of the total number of building disasters, however, due to the relatively large number of injured people, these incidents are very dangerous [1]. Moreover, the gas explosion often leads to significant material losses and fatalities. Proper assessment of the load-bearing structure after such incident requires an extensive knowledge of the behaviour of structures. The first authority, that issues a decision regarding further use is Construction Supervision Inspector. Until the demolition of the object is ordered, the next step is to provide expert report made by an authorized construction expert, whose aim is to assess the technical condition of the elements of the structure and to determine the scope of necessary repair works. Construction expert, who give such opinion during the assessment of objects immediately after such incident, often has limited access to structural elements, moreover these elements often are covered. Hence, the recommendations contained in these reports often do not include all of required construction works.
\end{abstract}

\section{Introduction}

Building disasters caused by gas explosions are not too frequent phenomenon, however, they cause significant material losses and a relatively large number of fatalities and injuries. The most tragic incidents, due to the consequences, caused by the gas explosion in Poland have been widely discussed among other in the paper "Katastrofy budowlane spowodowane wybuchem gazu" [1]. The gas explosion phenomena in enclosed space, called confined explosion, is well known and described in numerous papers $[2,3]$. One of the effects of these incidents is an explosion overpressure, that can be reduced by explosion relief openings. The phenomena of an explosion in enclosed spaces in the cubic shape proceed as deflagration, i.e. combustion occurs at a speed not higher than the speed of sound in the gas mixture before ignition [3]. In presented case, the dimensions of the rooms were similar, therefore it can be assumed that the premises had a cubic shape. In the Figure 1, the influence of explosion relief opening on changes of overpressure value generated by confined gas explosion, was presented. The graph of idealization was created based on values of explosion parameters, that were measured as part of windows resistance tests on the strength of an explosion [4].

* Corresponding author: aleksandra.bak@,wat.edu.pl 


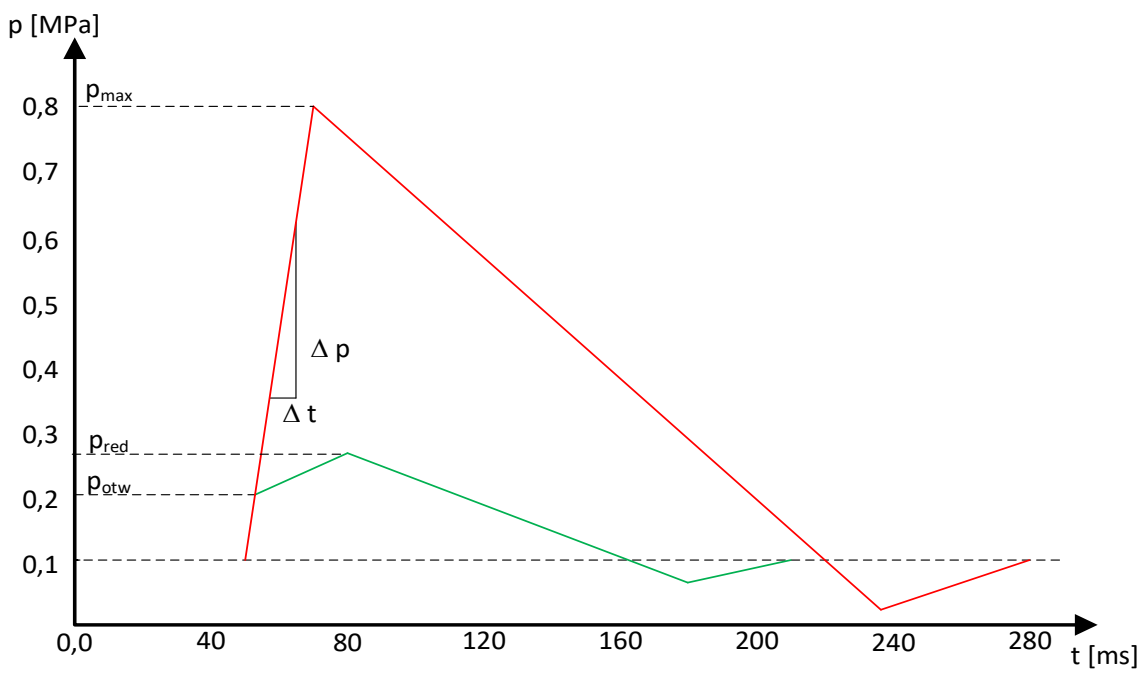

Fig. 1. The idealization of pressure changes during vented explosion.

On the graph of idealized explosion, the changes of the overpressure, generated by gas explosion in room without openings are presented by the red curve, while the green one presents the changes of pressure value in case of vented explosion. It can be noticed that in both cases the rate of overpressure rise, understood as $\Delta \mathrm{p} / \Delta \mathrm{t}$, is several times higher than the rate of its dispersion. Opening of the relief vent at overpressure of $p_{\text {otw }}$ allow to reduces the influence of an explosion on the load-bearing structure of the building from $p_{\max }$ to $p_{\text {red, }}$ which is also many times lower than maximum value (compare Figure 1). Explosion of gas used in residential and public buildings result in strain of the load-bearing elements with the overpressure value corresponding to the reduced pressure value $\mathrm{p}_{\text {stat }} \approx \mathrm{p}_{\text {red }}[3]$.

The occurrence of explosion relief openings in the walls of the building and its opening while explosion can reduce the explosion overpressure to a large extent and therefore protect the structure of the building from collapse. In the Figure 2, the building elements that performed the task of explosion openings, were presented [5]. This situation allowed to limit the impact of gas cylinders explosion, that took place in 2015, on the ground floor of a singlefamily residential building.

a)

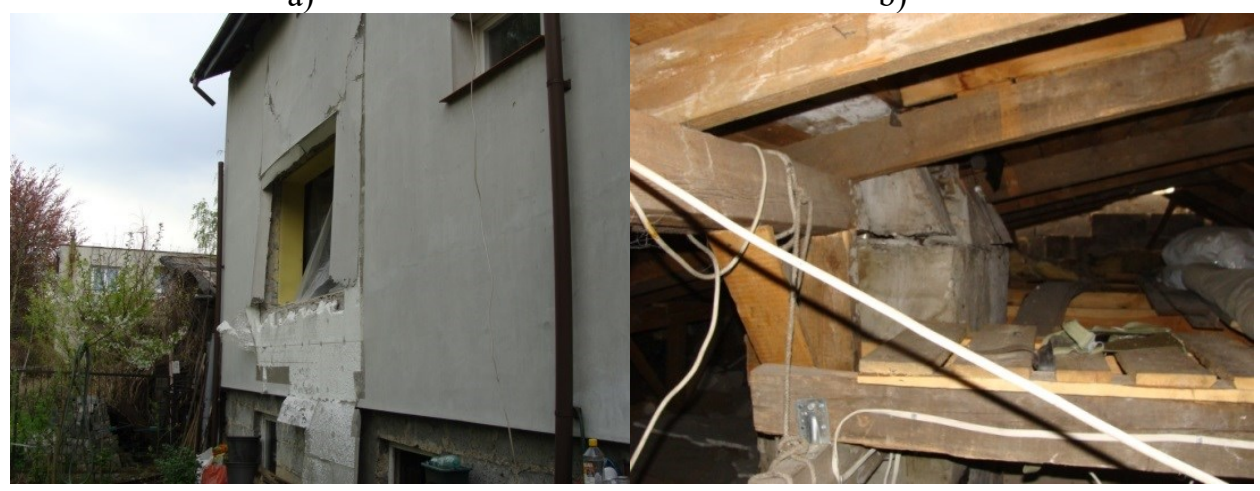

Fig. 2. Building elements, that acted as explosion relief openings while gas explosion a) window in the kitchen room, b) roof structure. 
The building was constructed using traditional technology with a brick structure and reinforced concrete ceilings above the ground floor and the basement. The ceiling under the roof was built as lightweight timber frame construction with gypsum board cladding. There were no significant damage to the door and window joinery on the first floor, because the force of the gas explosion directed upwards has been largely transferred through the ceiling structure to the roof truss [5]. Susceptible window fixing in the living room on the ground floor, lightweight partition walls on the first floor, ceiling above them and lightweight roof truss contributed to the proper direction of the explosion force. These elements acted as explosion relief openings and consequently the energy of gas explosion has been partially dissipated. The roof construction was lifted up by the force of explosion and fell back in, the result of which the roof had been deformed (twisted around the chimney shafts). The reduced explosion overpressure was sufficient to destroy the bathroom door on the ground floor, that were destroyed at the height of the lock due to the negative pressure, that pulled them inside the apartment. During evaluation of the building technical condition performed after the explosion, no significant damage of the elements of the load bearing masonry construction was found. Consequently the scope of repair works to fix or replace damaged building elements has been proposed.

If the door and window joinery is attached to the elements of load-bearing structure in a very durable way, the opening pressure of a relief opening (e.g. broken window) is equal to or greater than overpressure resulting in damage of the load-bearing structure. In this case, the building structure will be destroyed - Fig. 3 .

a)

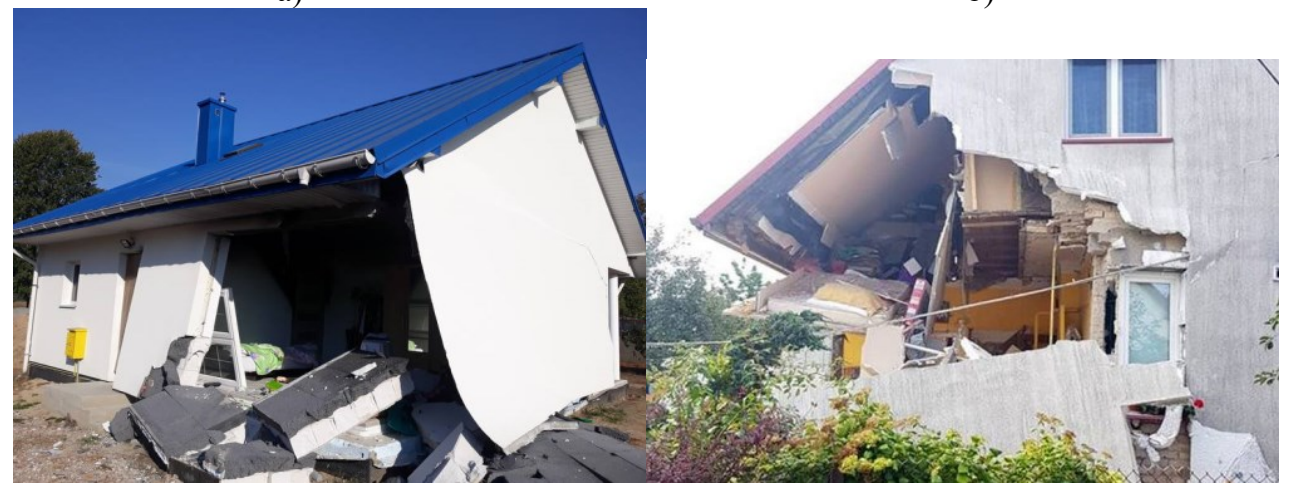

Fig. 3. The condition of single- family houses after the non-vented gas explosion a) residential building in Orzechowice [6], b) residential building in Hajnówka [7].

The changes in overpressure during a vented gas explosion in enclosed space depends on number of factors. To determine the maximum internal value of overpressure during gas explosions many analytical methods were presented [8-14]. These methods differ quite significantly both in computational assumptions and in the results of the calculations. Greater accuracy can be achieved using empirical and semi-empirical methods, based both on the results of experiments and the assessment of effects of explosions that have occurred so far [14-16].To estimate the maximum values of loads acting on the elements of a building during the explosion, it can be assumed, of high accuracy, that these are static loads of value equal to the reduced overpressure value (compare Fig. 1). 


\section{The condition of the building after the gas explosion}

The direct cause of the damage and destruction of the structural elements of the building was a gas explosion, that took place in one of the housing units (no. 109) located on the second floor of a three-storey multi-family residential building. Mentioned event took place on 20 May 2018. The first explosion was caused by the detonation of gas collected in the housing unit and the other three were explosions of gas cylinders located in various rooms of the apartment. The fire had a small extension - it was limited mostly to this housing unit and the flammable materials in this apartment. These explosions and fire resulted also in the damage and destruction of the parts of the building, i.e. the penultimate and the last storey, and the roof over the last staircase of the building. The fire brigade quickly extinguished the fire, there were no injured people.

Construction Supervision Inspector, ordered to develop a report on technical condition of multi-family residential building by the decision of 24/05/2015. Mentioned report included, in particular an assessment of the condition of the part of the building comprising two apartments (no. 109 and 106) and the identification of the scope of repair works in order to remove the identified irregularities.

As a result of the gas explosion, both the window and door joinery, as well as the load-bearing structure of the roof and partition walls, have been destroyed. The explosion also caused the damage of construction of the inter-floor ceiling between the apartments no. 106 and 109 [5]. The first of the assessed building elements was the supporting structure of the roof, which was made of channel slabs based on screen walls. These walls have been damaged due to the lifting up the ceiling over the last floor, that also caused the deformation and leakage of the roof - Fig. 4. The free-standing masonry chimneys and ventilation chimneys have also been damaged.

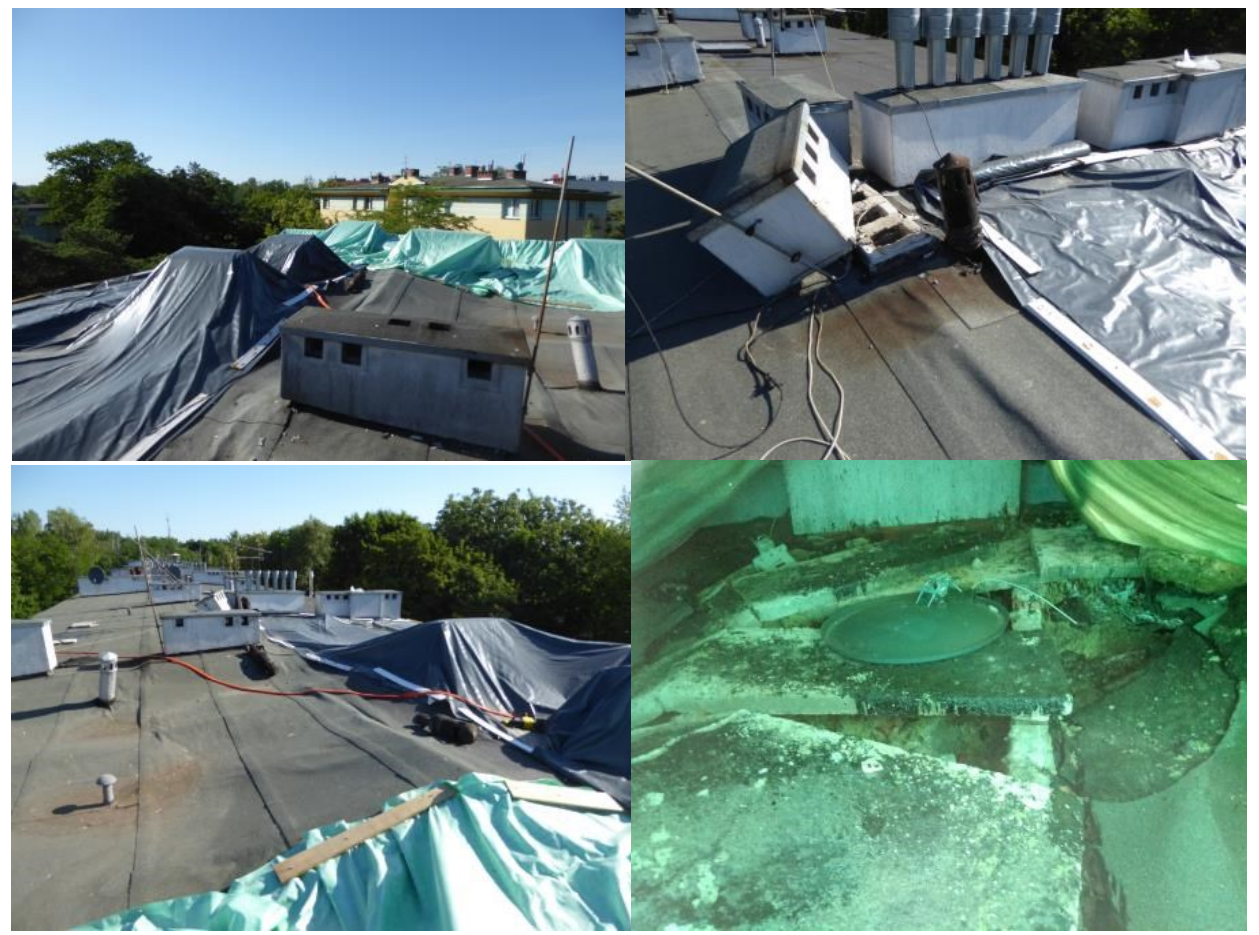

Fig. 4. The condition of the roof structure of the building after the explosion. 
The flat roof of the building was insulated with granulated wool. The explosion, lifted up the roof structure and fell down to its place without any imperfections - Fig. 5.

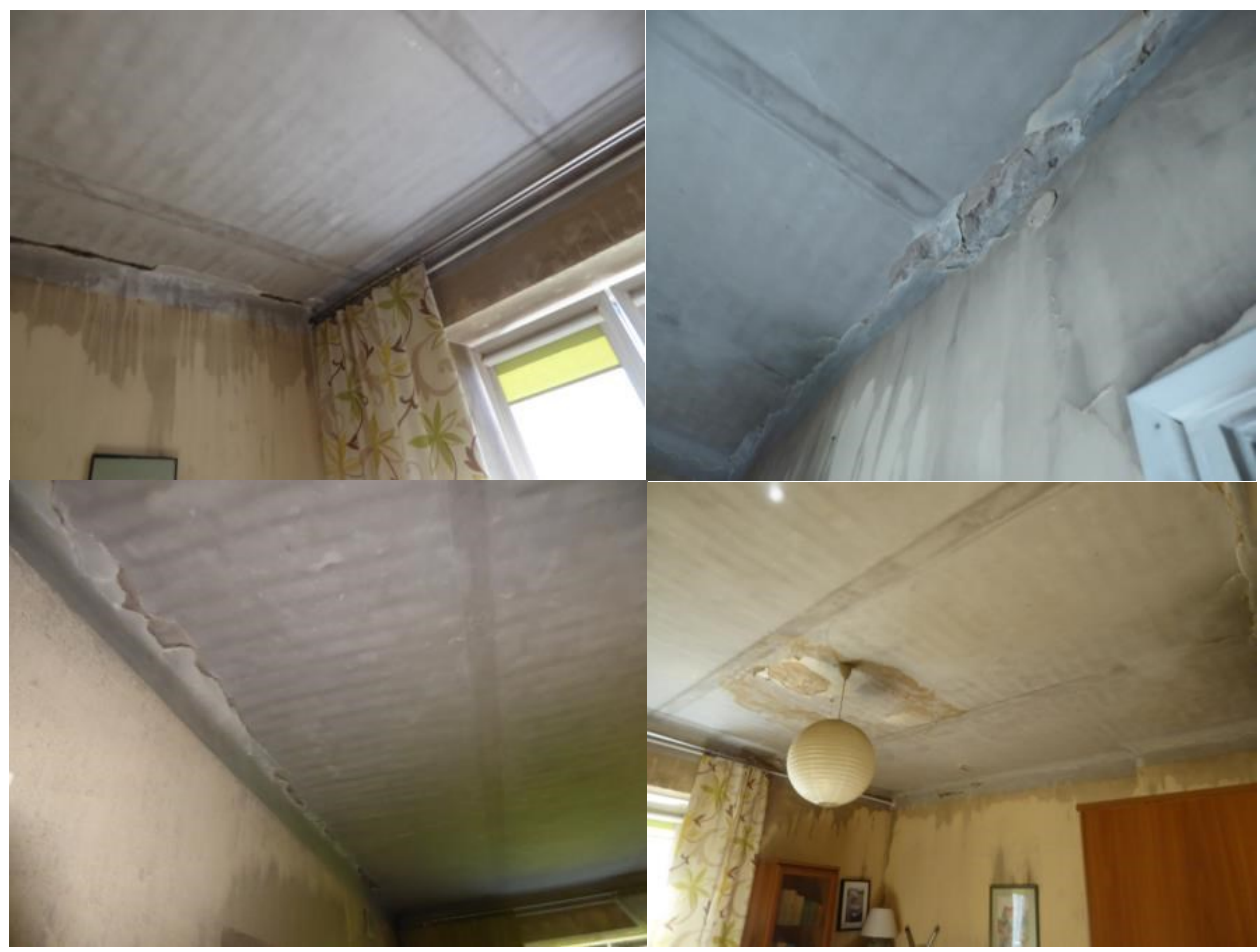

Fig. 5. Examples of damage of joints between walls and ceilings in the housing unit above the last floor.

The masonry partition wall between the apartments no. 109 and 110 had been completely destroyed - Fig. 6.
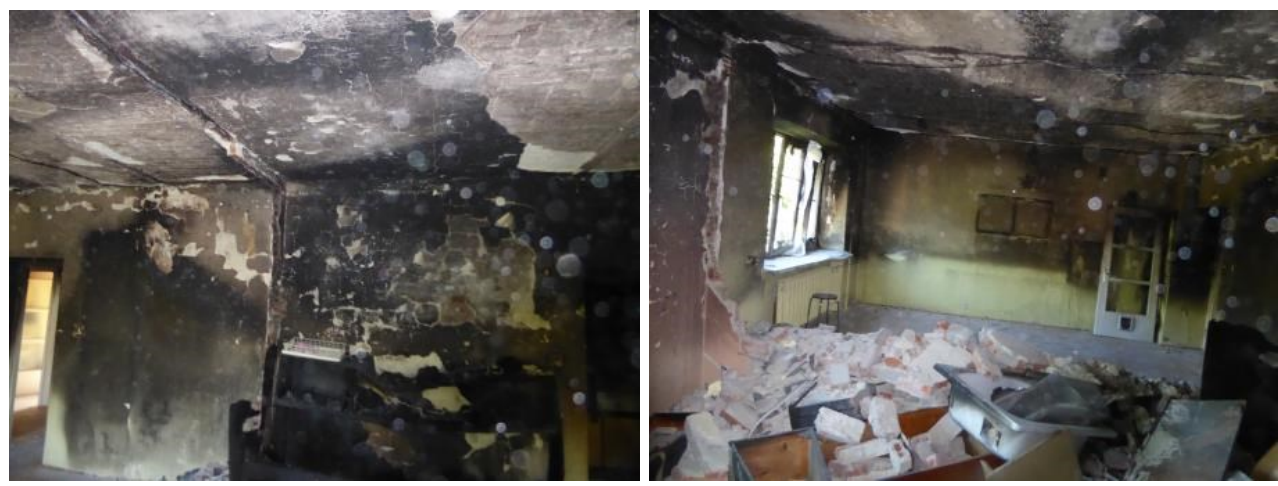

Fig. 6. The view of the destroyed partition wall between apartments no. 109 and 110 .

The fire have caused the greatest damage in the apartment no. 109, where all wall, floor and ceiling claddings had to be removed and utilized - Fig. 7. 


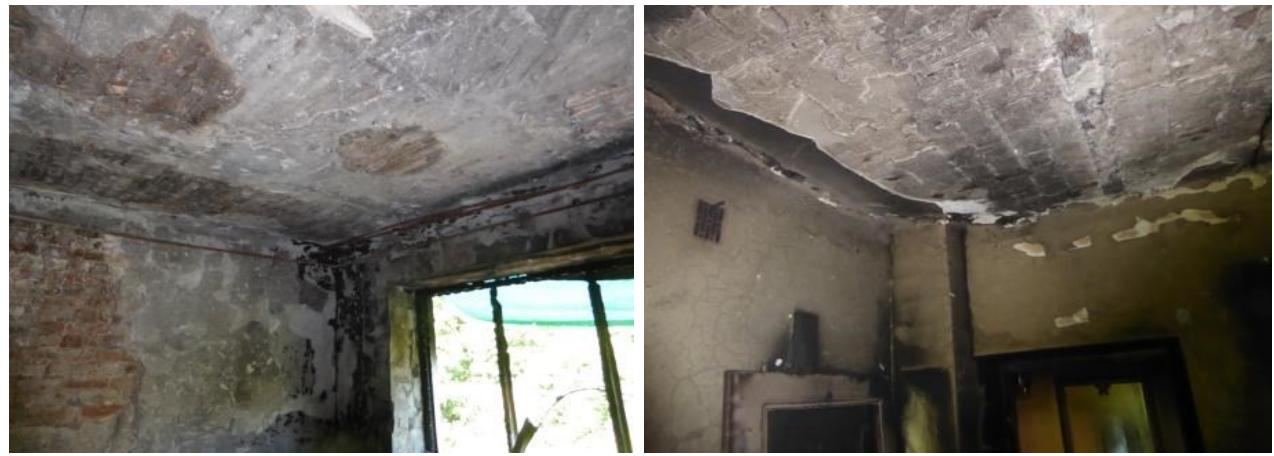

Fig. 7. The interior of the apartment no. 109 after the gas explosion.

The explosion of one of the gas cylinders caused the penetration of the inter-floor ceiling slab between apartments no. 109 and 106 - Fig. 8.

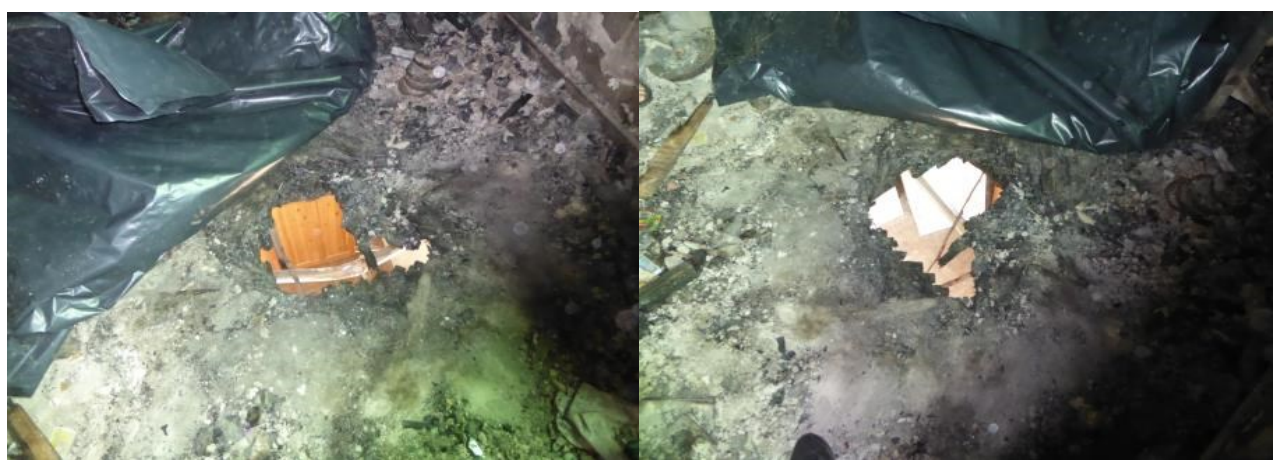

Fig. 8. The damage of the ceiling slab between apartments no. 106 and 109.

It was recommended to repair the damage of the ceiling by filling with a cast reinforced concrete slab, that should be made in combination with an undamaged parts of brick ceiling slab. The ceilings in the apartment no. 106, was constructed as metal framing with gypsum board cladding. According to the expert opinion, it was recommended to remove them and to assess the technical condition of the ceiling slabs. Door and window joinery, which acted as explosion relief openings, have been destroyed in the apartment where the explosion occurred. Additionally, as a result of the fire, one window in the neighbouring apartment (no. 110) has been destroyed - Fig. 9.

a)

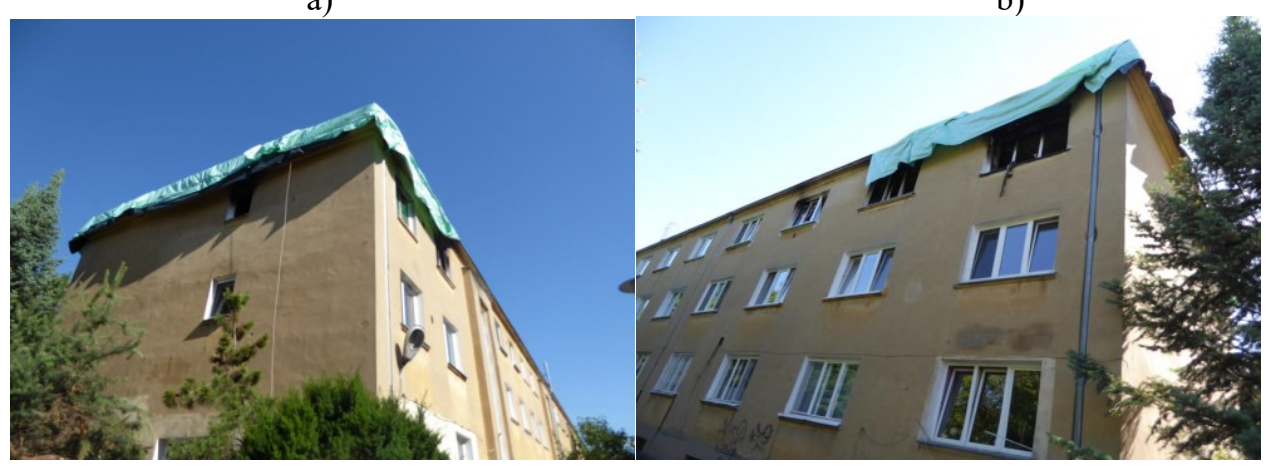

Fig. 9. The view of the damaged door and window joinery a) on the front and gable facades, b) on the rear facade. 
The housing units in the whole staircase were flooded, to a greater or lesser extent, by the water used to extinguish the fire. The apartment no. 110 was also heavily smoked, practically all of the walls and ceiling claddings of this apartment had to be removed. To sum up, gas explosions and the fire in the building were characteristic for explosions of poor fuel-air mixture. At the beginning the explosion caused a rapid increase of overpressure value, than the pressure was dispersed mainly by windows in apartment no. 109 and beneath the Klein ceiling slabs.

\section{Analysis of causes of damage and proposition of repairs}

The main damage and destruction of the building included the damage of the roof structure and finishing elements in the apartments no. 106, 109 and 110. The inspection of the building indicated the need to replace the structure of the ceiling over the last floor, which manager did not foresee. The need of the main damage repair was specified both in the technical expertise of the building and in the decision of the construction supervision. Mentioned decision has determined the scope of the necessary construction works, which were compatible with works proposed in the expert report [5]. Moreover, in the decision, during the renovation works, author's supervision was recommended. The aim of said supervision was to determine whether additional works, to ensure both the safety of the load-bearing structure and safety of users, were necessary. The scope of repair works had included the repair of entire roof and ceiling above the last storey of the last staircase of the building.

According to the expert recommendations, in the first place, the damaged and destroyed structural elements of the building and finishing elements should be removed:

- roof detailing over the entire staircase,

- roofing felt,

- damaged brick chimneys (including the ventilation chimneys),

- precast roof slabs,

- screen wall that supports roof slabs,

- Klein ceiling under the roof and the demolition of the knee wall.

It was also recommended to carry out construction works in accordance with the rules of the building industry, including measures and materials suitable for this type of work. Dismantling works were carried out manually with all necessary precautions, to avoid damage to elements which were to be preserved. Specific safety conditions while carrying out construction works are normalized by the Regulation of the Minister of Infrastructure of February 6, 2003 concerning the occupational health and safety during construction works. This Regulation describes detailed conditions of the safe carrying out of demolition works as well. During the renovation works, involving replacement of the roof, the contractor provided protection against an atmospheric precipitation. When the demolition works were completed, the ceiling was rebuilt. To this aim, a ceiling with steel beams and WPS slabs was constructed - Fig. 10. 
a)

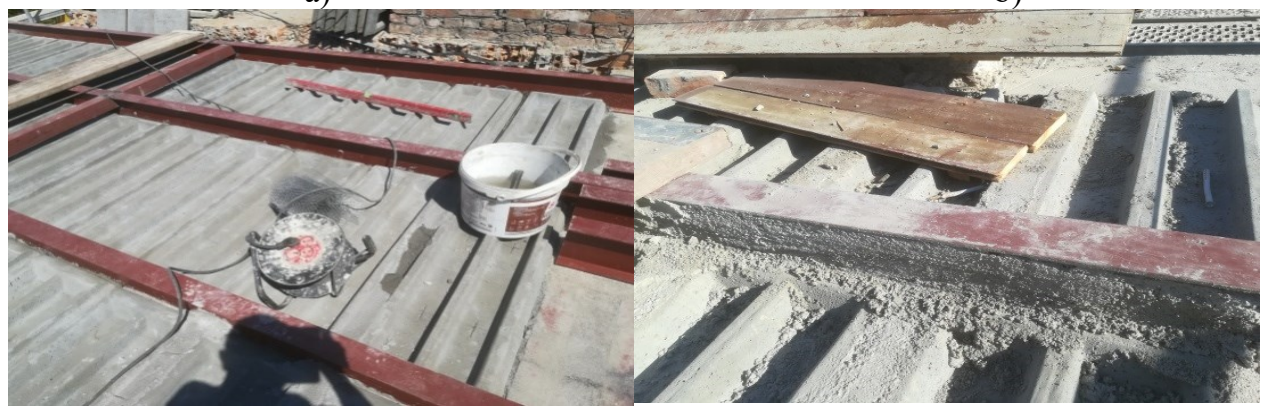

Fig. 10. Reconstructed structure of the ceiling over the last floor a) WPS slabs laid on steel beams, b) fillet welding of slabs.

The reconstructed ceiling structure was covered with a new reinforced concrete ring beam and on the steel beams of the ceiling, the walls supporting the roof slabs were made. Precast reinforced concrete channel slabs of $0.30 \mathrm{~m}$ width were used, that in comparison with other solutions, provided the smallest structural weight. When the roof slabs have been laid, on their perimeter an additional reinforced concrete ring beam was constructed - Fig. 11.

a)

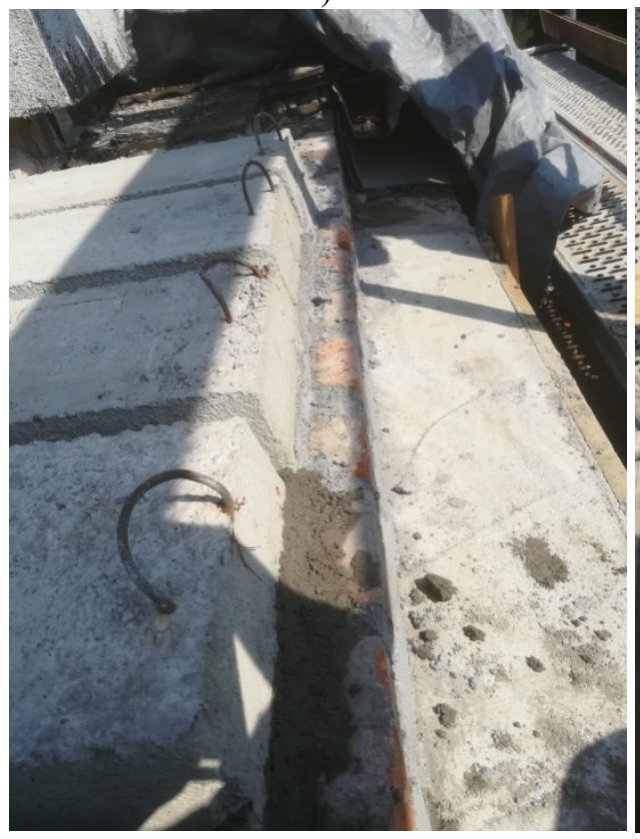

b)

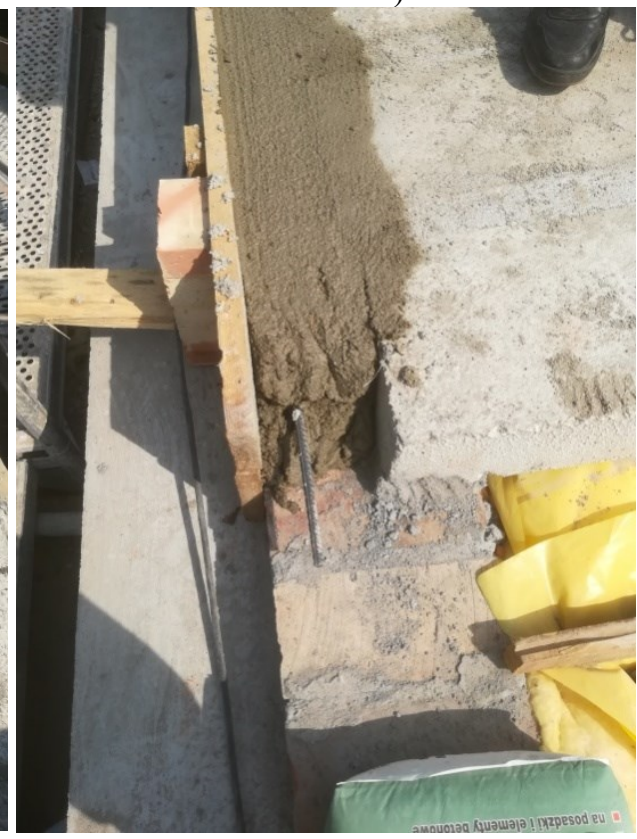

Fig. 11. The structure of the roof a) channel roof slabs, b) the ring beam around the slabs.

The replacement of the roof and destroyed door and window joinery at apartments no. 109 and 110 were carried out simultaneously. When the replacement of the roof was completed, the renovation of housing units began. The rubble after the fire and plasters from the walls and the ceilings have been removed in the first place, then the floors in the apartment no. 109 were dismantled to the structure of the Klein ceiling. On the cleaned ceiling, after application of anti-corrosive coating on steel beams, the joints were filled and a vapour-proof membrane was laid. Than the insulation with expanded clay filing was applied to the upper level of the beams, in the next step a sound insulation (of extruded polystyrene) was laid and a reinforced concrete smoothing underlayment of a thickness of $5 \mathrm{~cm}$, was poured. 
The destroyed partition wall between housing units no. 109 and 110 has been dismantled and rebuilt. The hole in the ceiling between apartments no. 106 and 109, created as a result of the explosion of one of the gas cylinders, was filled with cast concrete slab with bottom reinforcement. The explosion of the gas cylinder placed above the kitchen in the apartment no. 106, did not result in damage of the ceiling. After removing the gypsum board cladding, it turned out that the ceiling slab had been broken down on appreciable length. It was recommended to remove ceiling slab along the entire length between the load-bearing walls and filled in the same way as in the case of the hole that was created in the first cylinder explosion - Fig. 12.

a)

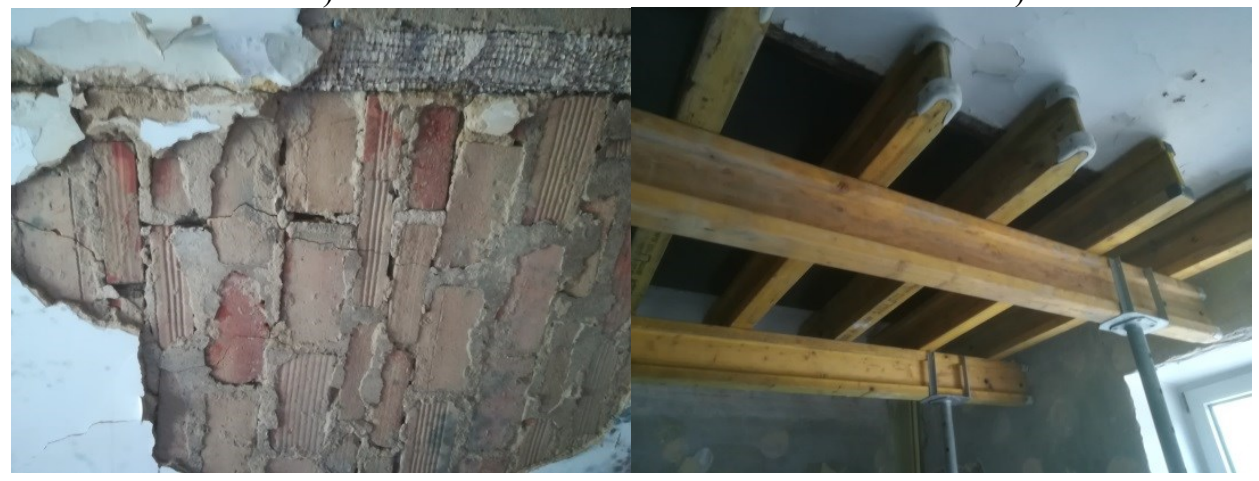

Fig. 12. The ceiling above the kitchen room in the apartment no. 106 a) the broken ceiling slab, b) formwork under the reinforced concrete slab.

It was recommended to start renovation works in residential premises after the completion of works associated to the construction of new roof structure. It was forbidden to stay in the apartments on the first floor, when the works aimed to repair the ceiling above the top floor and the roof structure were carried out.

\section{Discussion}

The gas explosion in buildings cause an exceptional loads, that are not considered in design of a structure. In case of gas explosion, the main load is caused by an explosive atmosphere [17], whose impact differs significantly from the effect of condensed explosives. Explosive atmospheres have significant spatial dimensions therefore the physicochemical changes are called as the volumetric explosions [18]. The loads parameters caused by this type of explosion significantly differ from those caused by the explosion of condensed materials. Both the dynamics of the explosion and the pressure changes from the blast, depend on the explosion source energy and the occurrence and activation of explosion relief openings, that in literature are often called as "vents" [18]. The most susceptible structural elements of the building are windows (which are destroyed at an overpressure of $1.5-50 \mathrm{kPa}$ ), curtain walls and partition walls (subject to damage at overpressure of $8-70 \mathrm{kPa}$ ) [18]. An overpressure of several dozen $\mathrm{kPa}$ may cause the destruction of structural elements, especially made of lightweight construction materials (e.g. aerated concrete, ceramic hollow bricks). Therefore, it would be advisable to build explosion relief openings, that would open at the lowest possible overpressure value.

In described situation, the first explosion was associated with explosive atmosphere, that has caused destruction of the windows at relatively low overpressure value, which allowed to protect the building against more serious damage. In spite of structural damage of the loadbearing structure of the ceiling and the destruction of screen walls that support the roof slabs, 
layout of the construction of the last storey of the building has not changed. Nevertheless, full evaluation of the technical condition of the load-bearing structure was possible after the uncovering of structural elements while carrying out the renovation works. Opinions and expert report, that are being prepared by highly qualified construction experts are crucial to determine the need for additional construction works, that aim to ensure the safety both of the load-bearing structure and the building users.

\section{Conclusions}

The volumetric explosion, explosions of three gas cylinders and the fire in the described building, caused the damages and destruction of the finishing elements. No significant damage of the elements of the masonry load-bearing structure was found. Therefore, the scope of repair works was proposed aimed to restore damaged elements. After completing both the scope of works proposed by expertise and supplementary works, whose necessity arose during the repairs, the building can be used. Then the renovation works aimed, among others, to removing the effects of flooding caused by rescue operation.

The analyzed cases have showed that it is advisable to equip the building with explosion relief openings, built of materials that can be destroyed at the lowest possible overpressure value. This recommendation applies to both existing and newly built buildings, where both gas installation and gas cylinders are used.

Among the construction works carried out after the explosion, there were no particularly dangerous works that would pose a special risk referred to in art. 21 a) of the Act of 7 July 1994 - Construction Law. However, due to the specific nature of the damage, constant expert author's supervision was ensured. During the repair works, partial technical acceptance were performed. Mentioned inspections aim to check whether the individual stages of construction works were carried out in in line with the technology specified in the expert report and the decision of the construction supervision. The scope of works increased due to the discovering of other damages and irregularities during demolition works. 


\section{References}

1. J. Szer, Katastrofy budowlane spowodowane wybuchem gazu (Proceedings of XXVII Scientific-Technical Conference on Structural Failures, Szczecin-Międzyzdroje 2015) [in Polish]

2. A. Papliński, Inżynieria Bezpieczeństwa Obiektów Antropogenicznych, 3 (2016) [in Polish]

3. T. Chyży, Biuletyn WAT, 3 (2014) [in Polish]

4. R. Rekucki, L. Szymańczyk, Raport z badań, Ocena odporności na sitę eksplozji okien wedtug normy PN-EN 13541:2012 [in Polish]

5. R. Chmielewski, L. Kruszka, Ekspertyzy, opinie techniczne z zakresu budownictwa, (WAT, 2005-2018) [in Polish]

6. https://poranny.pl/orzechowicze-wybuch-gazu-w-domu-jednorodzinnym-zawalila-siesciana-budynku-zdjecia/ga/13506231/zd/31237853, access: $23.10 .2018 \mathrm{r}$.

7. https://poranny.pl/hajnowka-wybuch-gazu-na-ulicy-spizowej /ar/13478401, access $23.10 .2018 \mathrm{r}$.

8. R.S. Benson, J.H. Burgoyne, British Shipbuilding Research Association, Report No 76, (1951)

9. D. Bradley, A. Mitcheson A, Combust. Flame, 32, pp. 221-236 (1978)

10. M. Fairweather, M.V. Vasey, Mathematical model of the prediction of overpressures generated by totally confined and vented explosions (Proceedings of 19th Symposium on Combustion, Haifa, 1982)

11. M.J. Sapko, A.L. Furno, J.M. Kuchta, Flame and pressure development of large scale CH4-air-N2 explosions. Bouyancy effects and venting requirements, (Bureau of Mines Report of Investigations R18176, 1976)

12. P. Canu, R. Rota, S. Carra, M. Morbidelli, Combust Flame, 80, pp. 49-64 (1990)

13. V.V. Molkow, R. Dobashi, M. Suzuki, T. Hirano, J. Loss. Prev. Process. Ind., 12, pp.147-156 (1999)

14. T. Chyży, Metoda analizy budynków mieszkalnych obciążonych nadciśnieniem w strefie wewnętrznego wybuchu gazu, (Oficyna Wydawnicza Politechniki Białostockiej, Białystok, 2009) [in Polish]

15. G. Lunn, Venting gas and dust explosions - a review, (An Icheme Industrial Fellowship report)

16. D. Razus, U. Krause, Fire Saf. J., 36, pp.1-23 (2001) [in Polish]

17. PN-EN 1127-1, Explosive atmospheres - Explosion prevention and protection

18. R. Krzewiński, A. Spychała, Ocena parametrów obciażeń obiektów budowlanych generowanych przez atmosfery wybuchowe (Proceedings of XIII Scientific and Technical Conference Eksploatacja infrastruktury w sytuacjach kryzysowych, Warszawa - Rynia, 2004) [in Polish] 